\title{
Occupancy Density Against ARI Diseases In Tolls In The Work Area of Wonorejo Puskesmas Samarinda City
}

\section{Author : \\ Ririn Pakaya', Apriyani²,}

\author{
First Author E-mail: \\ Ririn pakaya, \\ ririn.pakaya@mail.ugm. \\ ac.id, Universitas
} Gorontalo, Indonesia ${ }^{1}$ Second Author E-mail: Apriyani, riri.april4491@gmail.co m, Universitas Widya Gama Mahakam Samarinda, Indonesia ${ }^{2}$

DOI :10.24903/kujkm.v7i2.1190

Received : November 2021

Accepted : November 2021

Published : Desember 2021

P-ISSN: 2477-1880 E-ISSN: 2502-6623 Kesmas Uwigama : Jurnal Kesehatan Masyarakat

\begin{abstract}
Background: The under-five age group is a group with ARI patients with high morbidity and mortality rates. From january to june 2019, the wonorejo health center in Samarinda city recorded 1055 cases of ARI in all age groups, with the highest position being the toddler age group

Objectives:The purpose of this study was to determine the density of occupancy with ARI disease in toddlers aged 6-59months in the working area of the Wonorejo Health Center, Samarinda City.

Research Metodes: This type of research is a quantitative research with a cross sectional design. The population in this study were all toddlers aged 6-59 months who visited and registered (recorded in the child regiter book) at the Wonorejo Health Center in September 2019 as many as 110 toddlers. Based on the calculation of slovin samples as many as 86 people. Data analysii using Chi-Square test

Findings: The results showed that there was a relationship between residential density and ARI in children under five in the Wonorejo Health Center working area, Samarinda city

Conclusion: The public is expected to pay attention to the number of people in one room, preferably two adults and one toddler with a minimum area of $9 \mathrm{~m}^{2}$, because if in one house there is one family member whose ARI can infect others, epecially if sleeeping in one room which is less than $9 \mathrm{~m}^{2}$ and there is no ventilation or ventilation of less than $10 \%$ of the floor area.
\end{abstract}

Keywords: ARI, Occupancy density

\section{Abstrak}

Latar Belakang: Kelompok usia balita merupakan kelompok penderita ISPA dengan angka kesakitan dan angka kematian yang cukup tinggi. Sejak bulan Januari hingga Juni tahun 2019, Puskesmas Wonorejo Kota Samarinda mencatat 1,055 kasus ISPA pada semua kelompok umur, dengan posisi tertinggi adalah kelompok umur balita Tujuan: Tujuan penelitian ini untuk mengetahui kepadatan hunian dengan penyakit ISPA pada balita usia 6-59 bulan di wilayah kerja Puskesmas Wonorejo Kota Samarinda.

Metode Penelitian: Jenis penelitian ini penelitian kuantitatif dengan desain Cross Sectional. Populasi dalam penelitian ini adalah seluruh balita usia 6-59 bulan yan berkunjung dan terdaftar (tercatat di buku register anak) di Puskesmas Wonorejo pada bulan september tahun 2019 sebanyak 110 balita. Berdasarkan perhitungan slovin sampel sebanyak 86 orang. Analisis data menggunakan uji Chi-Square

Temuan: Hasil penelitian menunjukkan bahwa ada hubungan kepadatan hunian dengan penyakit ISPA pada balita di wilayah kerja Puskesmas Wonorejo Kota Samarinda.

Kesimpulan: Masyarakat diharapkan memperhatikan jumlah jiwa dalam satu kamar yang sebaiknya dua dewasa dan satu balita dengan luas minimal $9 \mathrm{~m}^{2}$, karena apabila dalam satu rumah terdapat salah satu anggota keluarga yang ISPA dapat menularkan kepada lainnya apalagi kalau tidur dalam satu kamar yang luasnya kurang dari $9 \mathrm{~m}^{2}$ dan tidak terdapat ventilasi atau ventilasi kurang dari 10\% luas lantai.

Kata kunci: ISPA; Kepadatan Hunian 


\section{Pendahuluan}

Infeksi Saluran Pernapasan Akut (ISPA) merupakan penyebab utama morbiditas dan mortalitas penyakit menular di dunia. ISPA merupakan salah satu masalah kesehatan yang ada di Negara berkembang dan Negara maju, hal ini disebabkan karena masih tingginya angka kesakitan (morbiditas) dan angka kematian (mortalitas). Menurut World Health Organization (WHO) menyebutkan insiden kelompok umur balita diperkirakan 0,29 episode per anak/tahun di negara berkembang dan 0,05 episode per anak/tahun di negara maju. Ini menunjukkan bahwa terdapat 156 juta episode baru di dunia per tahun dimana 151 juta episode $(96,7 \%)$ terjadi di negara berkembang. Artinya, insiden ISPA di negara berkembang adalah 2-10 kali lebih banyak dari pada negara maju. Tingkat mortalitas sangat tinggi pada bayi, anakanak dan orang lanjut usia, terutama di negara-negara dengan pendapatan perkapita rendah dan menengah. Sedangkan kasus ISPA terbanyak terjadi di India 43 juta, China 21 juta, Pakistan 10 juta, Bangladesh, Indonesia dan Nigeria masing-masing 6 juta episode (WHO, 2008)

Data di Indonesia, berdasarkan hasil laporan Riset Kesehatan Dasar (Riskesdas) tahun 2013 menunjukan prevalensi nasional ISPA di Indonesia adalah 25,0\% (terdapat 16 provinsi diatas angka nasional), tidak jauh berbeda dengan tahun 2007 yaitu 25,5\%. Sebanyak lima provinsi dengan prevalensi ISPA tertinggi, yaitu Nusa Tenggara Timur $41,7 \%$, Papua $31,1 \%$, Aceh 30,0\%, Nusa Tenggara Barat 28,3\% dan Jawa Timur 28,3\%. Sedangkan prevalensi di Provinsi Kalimantan Timur menempati urutan 24 tertinggi dari 33 provinsi dengan persentase sebesar 22,7\%.Indonesia tahun 2013 memiliki angka insiden 1,8 persen dan angka prevalensi 4,5 persen. Sedangkan period prevalence ISPA menurut karakteristik penduduk dengan ISPA yang tertinggi terjadi pada kelompok umur 1-4 tahun (25,8\%) (Dongky \& Kadrianti, 2016).

Penderita ISPA di Provinsi Kalimantan Timur pada periode yang sama persentasinya sebesar $3.5 \%$ atau berada pada urutan 16 dari 34 Provinsi di Indonesia. Meskipun berada di bawah angka rata-rata nasional, namun penyakit infeksi saluran pernapasan akut ini selalu menempati posisi sebagai penyakit tertinggi yang diderita masyarakat Kalimantan Timur dan tidak pernah bergeser selama 3 tahun berturut-turut. ISPA yang tidak tertangani dengan baik, bisa menimbulkan penyakit pneumonia. Data kasus ISPA di Kota Samarinda pada tahun 2017 sebanyak 1,662 kasus, jumlah kasus terbanyak ditemukan di wilayah kecamatan Sungai Kunjang yang meliputi Kelurahan teluk Lerong Ulu dan Kelurahan Karang Anyar (Dinkes Kota Samarinda, 2017).

Puskesmas Wonorejo merupakan fasilitas kesehatan dasar milik pemerintah yang melayani masyarakat di wilayah Kelurahan Karang Anyar dan Kelurahan Teluk Lerong Ulu. Cakupan wilayah kerja Puskesmas Wonorejo merupakan kawasan pemukiman padat penduduk dengan jumlah penduduk sebesar 38.560 jiwa dan Kepadatan Penduduk 160 jiwa $/ \mathrm{km}^{2}$ pada tahun 2018. Diketahui juga bahwa kepadatan penduduk di Kelurahan Teluk Lerong Ulu lebih tinggi daripada Kelurahan Karang Anyar.Hal tersebut tidak bisa dihindari, terutama bagi masyarakat pendatang yang tidak punya modal yang 
cukup namun nekat mengadu nasib dikota Samarinda, sehingga semakin banyak lahan kontrakan atau bangsalan, baik yang permanen maupun tidak permanen di kawasan ini. Dari faktor-faktor tersebut, banyak dampak yang ditimbulkan oleh fenomena kontrakan atau bangsalan di permukiman wilayah kerja Puskesmas Wonorejo, salah satunya adalah kondisi lingkungan yang memburuk dan berdampak buruk bagi kesehatan masyarakat yang tinggal disana. Menurut Kepala Dinas Perumahan dan Gedung Pemerintahan Provinsi DKI Jakarta, Novizal, Permukiman kumuh sirkulasi udaranya buruk, karena sinar matahari yang masuk terhalang oleh atap yang saling bertemu di sela-selanya, sehingga hal tersebut tidak baik bagi kesehatan (Virdani, 2012).

Hasil studi pendahuluan yang telah dilakukan di Puskesmas Wonorejo Kota Samarinda masih mendapati fenomena yang ditemukan di masyarakat terutama pada anak balita yakni ISPA yang tidak kunjung terselesaikan. Hal ini dibuktikan dengan angka kejadian ISPA yang selalu menempati urutan pertama dari 10 peringkat penyakit tertinggi yang diderita masyarakat di wilayah tersebutsejak Januari 2016 sampai dengan Desember 2018. Data selama 3 tahun terakhir menunjukkan ada 2,078 kasus, pada tahun 2016 tercatat 1,353 pasien penderita ISPA, sedangkan pada tahun 2017 tercatat hanya ada 644 kasus dan pada 2018 tercatat hanya 81 kasus. Meskipun menunjukkan adanya penurunan, namun posisi ini belum pernah bergeser. Sejak bulan Januari hingga Juni tahun 2019, Puskesmas Wonorejo Kota Samarinda mencatat 1,055 kasus ISPA pada semua kelompok umur yang terjadi di wilayah kerjanya. Kelompok umur penderita ISPA yang menempati posisi tertinggi adalah kelompok umur balita, tercatat ada 649 balita yang menderita penyakit ISPA dalam 6 bulan terakhir (Puskesmas Wonorejo, 2019).
Berdasarkan uraian di atas, kelompok usia balita merupakan kelompok penderita ISPA dengan angka kesakitan dan angka kematian yang cukup tinggi, sehingga dalam penanganannya diperlukan kesadaran yang tinggi baik dari masyarakat maupun petugas, terutama tentang beberapa faktor resiko yang mempengaruhi derajat kesehatan. Tingginya angka kejadian ISPA pada balita disebabkan oleh beberapa faktor resiko. Kementerian Kesehatan RI (2016) dalam buku pedoman pencegahan dan pengendalian infeksi saluran pernapasan akut menyebutkan bahwa terdapat beberapa faktor-faktor yang berkaitan dengan terjadinya infeksi pernapasan pada balita seperti imunisasi dan kepadatan penduduk.

Faktor lingkungan merupakan unsur penting yang berpengaruh terhadap munculnya kasus ISPA pada balita namun merupakan faktor yang paling sering diabaikan. Faktor lingkungan yang berpengaruh pada munculnya ISPA adalah yang berhubungan dengan kondisi lingkungan rumah. Mengingat sebagian besar waktu yang dihabiskan bayi dan balita adalah rumah dan lingkungannya (Afandi et al., 2012).

Faktor lingkungan tersebut antara lain kepadatan hunianadalah faktor lingkungan yang dominan mempengaruhi penderita ISPA. Tempat tinggal yang sangat padat (overcrowded) akan berpengaruh pada kelembaban suhu dalam ruangan, selain itu kepadatan penghuni di dalam ruangan yang berlebihan akan mempercepat transmisi mikroorganisme bibit penyakit dari seseorang ke orang lain, apabila salah satu anggota keluarga terkena penyakit infeksi, terutama penyakit ISPA akan mudah menular kepada anggota keluarga yang lain. Menurut Dongky \& Kadrianti (2016) yang menunjukkan bahwa kepadatan hunian dalam rumah memberikan kontribusi terhadap kejadian ISPA pada balita di Kabupaten Polewali Mandar. 


\section{Metode Penelitian}

Jenis penelitian ini penelitian kuantitatif dengan desain cross sectional. Populasi dalam penelitian ini adalah seluruh balita usia 6-59 bulan yang berkunjung dan terdaftar (tercatat di buku register anak) di Puskesmas Wonorejo tahun 2019 sebanyak 110 balita, berdasarkan perhitungan slovin sampel sebanyak 86 orang. Analisis data menggunakan uji chi-square

\section{Hasil Penelitian}

\section{Analisis Univariat}

\section{a. Kejadian ISPA}

Kejadian ISPA pada balita yang menjadi responden di wilayah kerja Puskesmas Wonorejo pada penelitian ini sebagai berikut:

Tabel 1. Distribusi frekuensi berdasarkan kejadian ISPA pada balita yang menjadi responden di wilayah kerja Puskesmas Wonorejo

\begin{tabular}{cccc}
\hline No & Kejadian ISPA & Frekuensi & $\mathbf{( \% )}$ \\
\hline 1 & Tidak ISPA & 33 & 38,4 \\
2 & ISPA & 53 & 61,6 \\
& Jumlah & $\mathbf{8 6}$ & $\mathbf{1 0 0}$ \\
\hline
\end{tabular}

Berdasarkan tabel 1 diperoleh gambaran bahwa dari 86 dari balita yang menjadi responden di wilayah kerja Puskesmas Wonorejo yang terlibat dalam penelitian ini sebagian besar ISPA berjumlah 53 responden (61,6\%), sedangkan tidak ISPA berjumlah 33 responden $(38,4 \%)$.

\section{b. Kepadatan Hunian}

Kepadatan hunian tempat tinggal pada balita yang menjadi responden di wilayah kerja Puskesmas Wonorejo pada penelitian ini sebagai berikut:

Tabel 2. Distribusi frekuensi berdasarkan kepadatan hunian tempat tinggal pada balita yang menjadi responden di wilayah kerja

\begin{tabular}{cccc}
\hline No & $\begin{array}{c}\text { Kepadatan } \\
\text { Hunian }\end{array}$ & Frekuensi & $\mathbf{( \% )}$ \\
\hline 1 & Memenuhi Syarat & 34 & 39,5 \\
\hline 2 & $\begin{array}{c}\text { Tidak Memenuhi } \\
\text { Syarat }\end{array}$ & 52 & 60,5 \\
\hline & Jumlah & $\mathbf{8 6}$ & $\mathbf{1 0 0}$ \\
\hline
\end{tabular}

Puskesmas Wonorejo

Berdasarkan tabel 2 diperoleh gambaran bahwa dari 86 dari balita yang menjadi responden di wilayah kerja Puskesmas Wonorejo yang terlibat dalam penelitian ini sebagian besar kepadatan hunian tidak memenuhi syarat berjumlah 52 responden $(60,5 \%)$, sedangkan memenuhi syarat berjumlah 34 responden $(39,5 \%)$.

2. Analisis Bivariat

a. Hubungan kepadatan hunian dengan penyakit ISPA pada balita di wilayah kerja Puskesmas Wonorejo Kota Samarinda.

Hubungan kepadatan hunian dengan penyakit ISPA pada balita di wilayah kerja Puskesmas Wonorejo Kota Samarinda pada penelitian ini dapat dilihat pada tabel sebagai berikut:

Tabel 3 Hubungan kepadatan hunian dengan penyakit ISPA pada balita di wilayah kerja Puskesmas Wonorejo Kota Samarinda

\section{Kejadian ISPA}

\begin{tabular}{|c|c|c|c|c|}
\hline & & & & \\
\hline No & $\begin{array}{c}\text { Kepadatan } \\
\text { Hunian }\end{array}$ & $\begin{array}{l}\text { Tidak } \\
\text { ISPA }\end{array}$ & ISPA & $\begin{array}{c}\mathbf{P} \\
\text { Value }\end{array}$ \\
\hline
\end{tabular}

$\begin{array}{lllllllll}1 & \begin{array}{l}\text { Memenuhi } \\ \text { Syarat }\end{array} & 18 & 20,9 & 16 & 18,6 & 34 & 39,5 & \\ & \begin{array}{l}\text { Tidak } \\ 2\end{array} & & & & & & & 0,043 \\ \begin{array}{l}\text { Memenuhi } \\ \text { Syarat }\end{array} & 15 & 17,4 & 37 & 43 & 52 & 60,5 & \\ & & & & & & & \\ & \text { Jumlah } & \mathbf{3 3} & \mathbf{3 8 , 4} & \mathbf{5 3} & \mathbf{6 1 , 6} & \mathbf{8 6} & \mathbf{1 0 0} & \end{array}$

Dari tabel tersebut terlihat dari 34 responden yang kepadatan hunian memenuhi syarat, proporsi tertinggi pada responden yang tidak ISPA berjumlah 18 responden (20,9\%), terdapat responden kepadatan hunian memenuhi syarat akan tetapi ISPA berjumlah 16 responden (18,6\%). Adapun dari 52 responden yang kepadatan hunian tidak memenuhi 
syarat, proporsi tertinggi pada responden yang ISPA berjumlah 37 responden $(43 \%)$, terdapat responden kepadatan hunian tidak memenuhi syarat akan tetapi tidak ISPA berjumlah 15 responden $(17,4 \%)$. Hasil uji statistik dengan menggunakan uji chi square diperoleh hasil $p$ value : 0,043 $<\alpha: 0,05$ sehingga Ho ditolak yaitu ada hubungan kepadatan hunian dengan penyakit ISPA pada balita di wilayah kerja Puskesmas Wonorejo Kota Samarinda.

\section{Pembahasan}

Berdasarkan hasil penelitian mengenaihubungan kepadatan hunian dengan penyakit ISPA pada balita di wilayah kerja Puskesmas Wonorejo Kota Samarinda diketahui bahwa kepadatan hunian memenuhi syarat sehingga responden tidak mengalami ISPA terdapat 18 responden $(20,9 \%)$, hal ini dikarenakan luas kamar lebih dari $9 \mathrm{~m}^{2}$ dan hanya 2 orang dewasa dengan 1 balita yang tidur di dalam kamar tersebut, sehingga mencegah penularan penyakit. Dimana hunian dengan tingkat kepadatan yang tinggi akan meningkatkan suhu dan kelembaban dalam ruangan akibat pengeluaran panas dari pernapasan penghuninya dan penyebaran penyakit-penyakit menular di rumah yang padat penghuninya cepat terjadi.

Kepadatan hunian yang memenuhi syarat akan tetapi responden mengalami ISPA terdapat 16 responden $(18,6 \%)$.Walaupun luas kamar lebih dari $9 \mathrm{~m}^{2}$ dan hanya 2 orang dengan 1 balita yang tidur di dalam kamar tersebut, namun balita memiliki daya tahan tubuh masih kurang baik yang membuat rentan ISPA. Selain itu, dinding rumah yang tidak memenuhi syarat terbuat dari bahan yang tidak kedap air yang dapat meningkatkan kelembaban rumah akibat rembesan ke dinding. Dinding merupakan komponen rumah yang mampu mencegah panas pada siang hari dan menahan panas pada malam hari sehingga menyebabkan kondisi suhu maupun kelembaban dalam rumah relatif sama. Dinding menjadi media bagi proses rising damp (kelembaban yang naik dari tanah) yang merupakan salah satu faktor penyebab kelembaban dalam rumah. Kondisi lembab ini akan menjadi prakondisi pertumbuhan kuman maupun bakteri patogen yang dapat menimbulkan penyakit bagi penghuninya.

Kepadatan hunian tidak memenuhi syarat sehingga responden mengalami ISPA terdapat 37 responden (43\%), hal ini dikarenakan rumah responden yang kecil sehingga kamar cukup terbatas luasnya kurang dari $9 \mathrm{~m}^{2}$ dan terdapat 2 orang dengan 1 balita yang tidur di dalam kamar tersebut. Selain itu, rumah yang lantainya tidak permanen lebih lembab dibandingkan dengan rumah yang lantainya permanen/sudah berubin. Rumah yang lantainya tidak permanen (tanah) mempunyai kontribusi besar terhadap kejadian ISPA karena lantai rumah yang terbuat dari tanah akan menyebabkan kondisi dalam rumah menjadi berdebu. Keadaan ini menjadi salah satu bentuk terjadinya pulusi udara dalam rumah. Debu dalam udara apabila terhirup akan menempel pada saluran nafas bagian bawah sehingga menimbulkan iritasi pada saluran pernafasan, akibatnya balita kesulitan bernafas.

Terdapat responden kepadatan hunian tidak memenuhi syarat akan tetapi tidak ISPA berjumlah 15 responden $(17,4 \%)$, dikarenakan rumah responden yang kecil sehingga kamar cukup terbatas luasnya kurang dari $9 \mathrm{~m}^{2}$ dan terdapat 2 orang dengan 1 balita yang tidur di dalam kamar tersebut, namun di kamar terdapat jendela yang dibuka setiap pagi sampai sore hari sehingga udara masuk. Selain itu, kamar selalu dibersihkan setiap harinya dari kotoran seperti debu.

Hasil uji statistik dengan menggunakan uji chi square diperoleh hasil $p$ value : 0,043 
$<\alpha$ : 0,05 sehingga Ho ditolak yaitu ada hubungan kepadatan hunian dengan penyakit ISPA pada balita di wilayah kerja Puskesmas Wonorejo Kota Samarinda. Hasil penelitian yang dilakukan ini relevan dengan penelitian Agungnisa (2019) yang menunjukkan bahwa ada hubungan kepadatan hunian dengan kejadian ISPA pada balita di Desa Kalianget Timur. Begitupula penelitian Syahidi et al. (2016) menunjukkan bahwa ada hubungan kepadatan hunian dengan kejadian ISPA pada balita di wilayah Puskesmas Tebet Barat. Begitupula penelitian Mardhani (2019)

bahwa terdapat hubungan yang signifikan antara kepadatan hunian rumah dengan kejadian penyakit pneumonia pada balita.

Hasil penelitian yang dilakukan pada kepadatan hunian rumah yang memenuhi syarat lebih sedikit terserang penyakit ISPA dibandingkan dengan kepadatan hunian rumah yang tidak memenuhi syarat. Hal ini dikarenakan rumah padat penghuni akan membuat proses pertukaran udara di dalam rumah tidak berjalan dengan baik, sehingga mempermudah penularan penyakit seperti ISPA karena penularannya ditransmisikan melalui udara. Semakin padat hunian maka perpindahan penyakit terutama penyakit yang transmisinya melalui udara akan semakin cepat dan mudah, karena itu kepadatan hunian adalah variabel yang memiliki peran dalam kejadian ISPA pada balita.

Kepadatan hunian di dalam rumah dapat menimbulkan efek negatif terhadap fisik, mental maupun moril bagi penghuninya. Kepadatan hunian memudahkan terjadinya penularan penyakit terutama melalui saluran pernafasan. Oleh karena itu selalu perhatikan luas rumah dan jumlah kamar tidur dengan jumlah orang yang tinggal di dalam rumah serta tetap memperhatikan kamar harus selalu bersih, mudah dibersihkan, cukup cahaya dan cukup ventilasi agar terhindar dari penyakit.

Menurut Firnanda et al., (2017) mengatakan bahwa tingkat kepadatan hunian yang tidak memenuhi syarat disebabkan karena luas rumah yang tidak sebanding dengan jumlah keluarga yang menempati rumah. Luas bangunan rumah yang sempit dengan jumlah anggota keluarga yang banyak dapat menyebabkan rasio penghuni dengan luas rumah seimbang. Kepadatan hunian ini memungkinkan bakteri maupun virus dapat menular melalui pernapasan dari penghuni rumah yang satu ke penghuni rumah yang lainnya bahkan hingga ke anak-anak yang masih di bawah umur artinya balita yang tinggal di rumah dengan penghuni padat mempunyai risiko tinggi untuk menderita pneumonia dibanding dengan balita yang tinggal di rumah dengan penghuni tidak padat.

\section{Kesimpulan}

Ada hubungan kepadatan hunian dengan penyakit ISPA pada balita di wilayah kerja Puskesmas Wonorejo Kota Samarinda $(p$ value : $0,043<\alpha: 0,05$ ).

\section{Referensi}

Afandi, A. D. E. I., Masyarakat, F. K., \& Epidemiologi, P. S. (2012). Universitas Indonesia Hubungan Lingkungan Fisik Rumah Dengan Anak Balita Di Kabupaten Wonosobo Provinsi Jawa Tengah Tahun 2012 Tesis Anak Balita Di Kabupaten Wonosobo Provinsi Jawa Tengah Tahun 2012.

Agungnisa, A. (2019). Physical Sanitation of the House that Influence the Incidence of ARI in Children under Five in Kalianget Timur Village. Jurnal Kesehatan Lingkungan, 11(1), 1. https://doi.org/10.20473/jkl.v11i1.20 19.1-9

Dinkes Kota Samarinda. (2017). Profil Kesehatan Kota Samarinda Tahun 2017.

Dongky, P., \& Kadrianti, K. (2016). Faktor Risiko Lingkungan Fisik Rumah 
Dengan Kejadian Ispa Balita Di

Kelurahan Takatidung Polewali

Mandar. Unnes Journal of Public Health,

5(4), 324.

https://doi.org/10.15294/ujph.v5i4.1

3962

Firnanda, N., Junaid, \& Jafriati. (2017).

Analisis Spasial Kejadian Penyakit Infeksi Saluran Pernapasan Akut (Ispa)

Pada Balita Di Kelurahan Puwatu

Tahun 2017. Jimkesmas (Jurnal Ilmiah Mahasiswa Kesehatan Masyarakat), 2(7), 1-10.

Kementerian Kesehatan RI. (2016). Pedoman Pencegahan dan Pengendalian Infeksi Saluran Pernapasan Akut.

Mardhani, R. P. P. K. (2019). Hubungan Faktor Lingkungan Fisik Rumah, Status Pendidikan Ibu, Dan Status Pekerjaan Ibu Terhadap Kejadian Pneumonia Balita Di Wilayah Kerja Puskesmas. Jurnal Sport Science And Health, 1(3), 233-242.

Puskesmas Wonorejo. (2019). Sistem Informasi Kesehatan Daerah Kota Samarinda.

Syahidi, M. H., Gayatri, D., \& Bantas, K. (2016). Faktor-faktor yang Mempengaruhi Kejadian Infeksi Saluran Pernapasan Akut (ISPA) pada Anak Berumur 12-59 Bulan di Puskesmas Kelurahan Tebet Barat, Kecamatan Tebet, Jakarta Selatan, Tahun 2013. Jurnal Epidemiologi Kesehatan Indonesia, 1(1), 23-27. https://doi.org/10.7454/epidkes.v1i1. 1313

Virdani, R. (2012). "Saat Pembangunan Rumah Susun, tak Ada Relokasi Warga" dalam Republika Online". Republika Online.

WHO. (2008). Epidemic-prone and pandemic-prone acute respiratory diseases: Infection prevention and control in helath-care facilities. Who. Indonesia Partner in Development, 53(2), https://doi.org/10.1017/CB09781107 415324.004 